\title{
INSECTICIDE APPLICATION SPEED IN THE CONTROL OF LEPIDOPTERAN PESTS IN SOYBEAN ${ }^{1}$
}

\author{
LENIO CESAR MORAES DE CAMARGO²*, DANILO DE BRITO GARCIA ${ }^{3}$, OTÁVIO JORGE GRÍGOLI ABI SAAB ${ }^{2}$, \\ AMARILDO PASINI ${ }^{2}$, DANILO AUGUSTO SARTI ${ }^{4}$, CARLOS TADEU DOS SANTOS DIAS ${ }^{4}$
}

\begin{abstract}
During the chemical control of pests, diseases and weeds, great importance is given to the phytosanitary product and little attention to the application technology. The control of soybean pests did not escape the general rule and, therefore, some pests known as secondary, and even nonexistent, became responsible for great damage to the soybean crop. The objective of this work was to test the application of insecticide at different speeds ( 5 and $16 \mathrm{~km} \mathrm{~h}^{-1}$ ) by varying the rates of application in 108 to 110 and 199 to 216 $\mathrm{L} \mathrm{ha}^{-1}$ to quantify the difference in the coverage percentage of the applied insecticide in the canopy of soybean plants, and to verify the interaction of these factors with efficacy parameters for the control of caterpillars (Helicoverpa armigera and Chrysodeixis includens). In general, the highest leaf coverage by the insecticide was observed in the upper part of the canopy, regardless of the rate and speed of application, resulting in lower leaf damage. For the middle and lower thirds of the plant, the decrease in speed influenced more the decrease in leaf damage by the caterpillars than the increase in the spray volume.
\end{abstract}

Keywords: Application technology. Percentage of coverage. Chemical control. Glycine max. Soybean caterpillars.

\section{VELOCIDADE DE APLICAÇÃO DE INSETICIDA NO CONTROLE DE LEPIDÓPTEROS PRAGA NA SOJA}

\begin{abstract}
RESUMO - Durante o controle químico de insetos, doenças e plantas daninhas, dá-se muita importância ao produto fitossanitário e pouca atenção à técnica de aplicação. O controle de pragas da soja não escapa à regra geral e, dessa forma, algumas pragas ditas como secundárias, e até mesmo inexistentes, passaram a ser responsáveis por grandes prejuízos. O objetivo desse trabalho foi avaliar a aplicação de inseticida em diferentes velocidades (5 e $16 \mathrm{~km} \mathrm{~h}^{-1}$ ) variando as taxas da aplicação entre 108 a 110 e 199 a $216 \mathrm{~L} \mathrm{ha}^{-1}$ para quantificar a diferença na porcentagem de cobertura do inseticida aplicado no dossel de plantas de soja e verificar a influência desses fatores em parâmetros de eficácia para o controle das lagartas (Helicoverpa armigera e Chrysodeixis includens). De modo geral, a maior cobertura foliar pelo inseticida foi observada no terço superior do dossel, independente da taxa e velocidade de aplicação, refletindo em menores injúrias foliares. Para os terços médio e inferior, a diminuição da velocidade teve mais influência na diminuição do dano foliar do que o aumento do volume.
\end{abstract}

Palavras-chave: Tecnologia de aplicação. Porcentagem de cobertura. Controle químico. Glycine max. Lagartas da soja.

\footnotetext{
${ }^{*}$ Corresponding author

${ }^{1}$ Received for publication in $03 / 15 / 2019$; accepted in $12 / 05 / 2019$.

Paper extracted from the doctoral thesis of the first author.

${ }^{2}$ Department of Agronomy, Universidade Estadual de Londrina, Londrina, PR, Brazil; lenio_cmc@hotmail.com - ORCID: 0000-00034477-9864, abisaab@uel.br - ORCID: 0000-0002-1757-636X, pasini@uel.br - ORCID: 0000-0001-6962-1217.

${ }^{3}$ Department of Crop Science, Escola Superior de Agricultura "Luiz de Queiroz", Piracicaba, SP, Brazil; danilo.bgarcia@gmail.com ORCID: 0000-0002-0005-2455.

${ }^{4}$ Department of Math, Chemistry and Statistics, Escola Superior de Agricultura "Luiz de Queiroz", Piracicaba, SP, Brazil; danilo.estat@gmail.com - ORCID: 0000-0001-8148-2803, ctsdias@usp.br-ORCID: 0000-0003-1015-1761.
} 


\section{INTRODUCTION}

In order to achieve success in an application, the spray drops need to be deposited on the desired target. Reduction in the cost of application and increase in the operational capacity of the devices have set the directions that determine the strategies in pesticide application technology. Thus, with the increase in displacement speed, the operational capacity increases. However, factors such as operating pressure, flow rate and nozzle outlet orifice should be regulated in such a way to satisfy the quality of applications, adjusting the application technology to the required conditions (WEBER et al., 2017).

Due to the environmental, energy, economic and operational costs associated with their use, applications in liquid form tend to use less and less water volume per area. This trend is mainly linked to the cost of transport to the field and the waste of time due to interruptions, displacement and refill of the sprayers (BALAN et al., 2008). However, the higher the application rate, the greater the increase in the percentage of coverage on the applied target (ROMÁN et al., 2009) and the higher the tendency of penetration of the drops in the canopy of crops.

Pest-insect control through chemical products has been widely used in agricultural environments (CZEPAK et al., 2013). However, little attention is paid to the application technology when performing the chemical control of insects, weeds and diseases in crops. Some pests considered secondary, and even nonexistent, became responsible for major damage to the crop. For instance, it is possible to mention the appearance of Heliothis virescens, Helicoverpa zea and Helicoverpa armigera as pest-insects of real importance in this crop, especially in 11-12 and 1213 harvests (AVILA; VIVAN; TOMQUELSKI, 2013).

In addition to the incoming pests in the pestinsect complex in the scenario of soybean production in the country, other pests already catalogued in the crop, such as Chrysodeixis includens, have been shown to be more difficult to control, especially due to the life habit of the caterpillar, in the lower canopy of the crop. One of the consequences observed in this situation was the uncontrolled use of insecticides, which, in addition to unnecessarily increasing the costs for farmers, ultimately cause biological imbalance and consequently increased risk of resistance to the insecticides available on the market (CZEPAK et al., 2013). In this scenario, Azevedo (2007) reports that the development of an integrated pest management became of fundamental importance for a successful production of this oilseed crop.
Thus, the objective of this study was to test the application of insecticide at different speeds ( 5 and $16 \mathrm{~km} \mathrm{~h}^{-1}$ ) and application rates (108 to 110 and 199 to $216 \mathrm{~L} \mathrm{ha}^{-1}$ ) to quantify the difference in the percentage of coverage for the insecticide applied in the canopy of soybean plants and, also, to verify the influence of these factors on efficacy parameters for the control of caterpillars (Helicoverpa armigera and Chrysodeixis includens).

\section{MATERIAL AND METHODS}

The experiment was carried out in the 2016/17 soybean harvest, in the municipality of Paulínia-SP, Brazil. According to Köppen's classification, the climate is Cwa (hot and rainy summer, average annual rainfall of $1600 \mathrm{~mm}$ ), while the soil of the region is classified as Latossolo Vermelho Distrófico (Oxisol) (EMBRAPA, 1999).

The study was conducted using the transgenic soybean variety 'Potência RR', with indeterminate growth habit, sown on September 19, 2016 (0.5 m between rows and 14 seeds $\mathrm{m}^{-1}$ ) and fertilized with $200 \mathrm{~kg} \mathrm{ha}^{-1}$ of the formulation 2-20-20 (NPK) in the planting furrow.

In the field, the experiment was delineated in randomized blocks and in a 2 [application rates (108 to 110 and 199 to $\left.216 \mathrm{~L} \mathrm{ha}^{-1}\right)$ ] x 2 [application speeds $\left(5\right.$ and $\left.16 \mathrm{~km} \mathrm{~h}^{-1}\right)$ ] factorial scheme, with four replicates, and the evaluations were carried out for each third of the soybean plant (upper, middle and lower). To evaluate the pesticide penetration capacity in the plant canopy, the study was carried out after the soybean interrow was covered, at the phenological stage R4.

The insecticide Indoxacarb (15\% $\quad$ EC) $\left(\right.$ Avatar $\left.^{\circledR}\right)$ (chemical group of oxadiazine) was used at a dose of $400 \mathrm{~mL} \mathrm{ha}^{-1}$. The insecticide was applied with a Jacto ${ }^{\circledR}$ sprayer, AM12 model, with 11-m-long boom. Application rates, spray nozzles, operating pressures and application speeds are described in Table 1. To maintain the average drop sizes at different application rates, it was necessary to use different operating pressures (Table 1). The tractormounted spraying device regulations were made to produce medium drops $(200$ to $250 \mu \mathrm{m})$ for all treatments. During spraying, the boom was positioned $0.50 \mathrm{~m}$ above the soybean canopy and the nozzles were spaced by $0.50 \mathrm{~m}$. The plot area was $200 \mathrm{~m}^{2}(10 \mathrm{~m} \times 20 \mathrm{~m})$, with a usable area of $45 \mathrm{~m}^{2}(5$ $\mathrm{m} \times 9 \mathrm{~m}$ ), and the plots distanced and arranged in such a way to enable the stabilization of the application equipment within the usable plot adopted. 
Table 1. Description of the application rates and speeds, spray nozzles and pressure used in the experiment, with the product Indoxacarb (150 EC) applied at the phenological stage R4 in soybean crop. Paulínia-SP, Brazil.

\begin{tabular}{lccc}
\hline $\begin{array}{l}\text { Application rate } \\
\left(\mathrm{L} \mathrm{ha}^{-1}\right)\end{array}$ & $\begin{array}{c}\text { Application speed } \\
\left(\mathrm{Km} \mathrm{h}^{-1}\right)\end{array}$ & $\begin{array}{c}\text { Spray nozzle } \\
(\mathrm{XR})\end{array}$ & Pressure (bar) \\
\hline 110 & 5 & 110.02 & 1.0 \\
108 & 16 & 110.04 & 2.5 \\
199 & 5 & 110.03 & 1.5 \\
216 & 16 & 110.08 & 2.5 \\
\hline
\end{tabular}

Applications were carried out in the morning, starting at 09:20 h, with a maximum duration of 2:30 h. The climatic data during the applications were 25 ${ }^{\circ} \mathrm{C}$ and $27{ }^{\circ} \mathrm{C}$ (temperature), 63\% and 61\% (RH), 4 $\mathrm{km} / \mathrm{h}$ and $2.5 \mathrm{~km} / \mathrm{h}$ (wind speed), and cloudiness of $66 \%$.

To evaluate the leaf coverage of the insecticide, a PVC rod was installed in the center of each plot, where water-sensitive papers (76 x 26 $\mathrm{mm}$ ) were positioned (HALLEY et al., 2008). These papers were placed with the upper side up at three heights to simulate the strata: lower $(0.2 \mathrm{~m})$, middle $(0.5 \mathrm{~m})$ and upper $(0.8 \mathrm{~m})$. The supports were placed close to soybean plants in the center of the plot. After the applications, the water-sensitive paper cards were collected and stored in plastic PVC film to avoid contamination by air moisture. Insecticide coverage was characterized using a scanner, where the water-sensitive papers were scanned (spatial resolution of 600 non-interpolated dpi, with colors in 24 bits) and the images were later processed using the Program Conta-Gotas ${ }^{\circledR}$ (CANTERI et al., 2001), specific for this purpose.

Leaves were collected at 1 and 7 days after insecticide application (DAA). Forty-eight soybean leaflets were collected per caterpillar species evaluated in each third of the canopy (upper, middle and lower) of the plots, i.e., in each replicate of the treatments applied in the field (Table 1). The material was placed in plastic trays with individual cells $(5.5 \times 3.5 \mathrm{~cm})$ for each leaflet. These leaflets were covered with previously moistened absorbent paper and then infested with lepidopteran pests of soybean. Helicoverpa armigera and Chrysodeixis includens (Lepidoptera: Noctuidae) caterpillars from susceptible populations from the field were used, with the cultures to multiply these caterpillars established in the laboratory, maintained under controlled conditions of relative humidity $(\mathrm{RH} \%)$ $(70 \pm 20)$, photophase $(14 \mathrm{~h})$ and temperature $(25 \pm 1$ $\left.{ }^{\circ} \mathrm{C}\right)$. Moths were fed with solution of honey $(5 \%)$ and water, while the young stage of insects was raised with a natural diet (soybean leaves), maintained until they reached the 3rd-4th instar, when they were used for the study. To evaluate the treatments, leaf damage caused by the caterpillars was observed at 3 and 7 DAI (days after infestation).
For the coverage data $(\%)$, the means were subjected to analysis of variance and, when significant, were compared by Tukey test at 5\% significance level (upper and middle thirds with transformation $\mathrm{x}^{0.2}$ ). For data that did not meet the assumptions of the analysis of variance (lower third), as there was no interaction between the factors speed and application rate, it was chosen to use Friedman's nonparametric test and Fisher's LSD test on the ranks with Bonferroni correction as a means separation test (CONOVER, 1999). For damage data $(\%)$, as they did not meet the assumptions of the analysis of variance, Kruskal-Wallis nonparametric test on the ranks and Fisher's LSD test on the ranks with Bonferroni correction were used as a means separation test.

\section{RESULTS AND DISCUSSION}

No interaction was observed between the rates and speeds of Indoxacarb application for the leaf coverage parameter in any of the three thirds $(P$ $=0.65,0.72$ and 0.12 , respectively, for the upper, middle and lower thirds). The upper third of the soybean plant showed highest leaf coverage by the insecticide, followed by the middle third and lower third.

Based on an individual analysis of each third, for the upper and middle thirds, the use of application rates from 199 to $216 \mathrm{~L} \mathrm{ha}^{-1}$ did not promote a more homogeneous insecticide distribution in the canopy of soybean plants when compared to the rates from 108 to $110 \mathrm{~L} \mathrm{ha}^{-1}$ (Table 2). These two thirds were influenced by the application speed, and the speed of $5 \mathrm{~km} \mathrm{~h}^{-1}$ led to greater coverage than the speed of $16 \mathrm{~km} \mathrm{~h}^{-1}$. Greater leaf coverage in the upper third of soybean plants with application of phytosanitary products has been reported, with volumes ranging from $20 \mathrm{~L} \mathrm{ha}{ }^{-1}$ (REIS, 2012) to $250 \mathrm{~L} \mathrm{ha}^{-1}$ (FARINHA et al., 2009).

For the lower third, the difference occurred between applications at $5 \mathrm{~km} \mathrm{~h}^{-1}$, regardless of the application rate, and the application at $16 \mathrm{~km} \mathrm{~h}^{-1}$ for the lowest application rate $\left(108 / 110 \mathrm{~L} \mathrm{ha}^{-1}\right)$, also indicating the relevance of reducing speed for better target achievement (Table 2). 
Table 2. Estimation of leaf coverage (\%) by Indoxacarb (15\% EC) using water-sensitive papers in different thirds of a PVC support at R4 phenological stage in soybean. Paulínia-SP, Brazil.

\begin{tabular}{|c|c|c|}
\hline \multicolumn{3}{|c|}{ Leaf Coverage (\%) } \\
\hline \multicolumn{3}{|c|}{ Upper third $^{1}$} \\
\hline & \multicolumn{2}{|c|}{ Application speed } \\
\hline Application Rate & $5 \mathrm{~km} \mathrm{~h}^{-1}$ & $16 \mathrm{~km} \mathrm{~h}^{-1}$ \\
\hline$\left(108 / 110 \mathrm{~L} \mathrm{ha}^{-1}\right)^{2}$ & $69.7 \mathrm{Aa}$ & $15.8 \mathrm{Ba}$ \\
\hline$\left(199 / 216 \mathrm{~L} \mathrm{ha}^{-1}\right)$ & $72.8 \mathrm{Aa}$ & $18.0 \mathrm{Ba}$ \\
\hline $\mathrm{CV} \%$ & \multicolumn{2}{|r|}{$3.48^{10.0 \mathrm{Da}}$} \\
\hline \multicolumn{3}{|c|}{ Middle Third $^{1}$} \\
\hline & \multicolumn{2}{|c|}{ Application speed } \\
\hline Application Rate & $5 \mathrm{~km} \mathrm{~h}^{-1}$ & $16 \mathrm{~km} \mathrm{~h}^{-1}$ \\
\hline$\left(108 / 110 \mathrm{~L} \mathrm{ha}^{-1}\right)$ & $11.8 \mathrm{Aa}$ & $4.0 \mathrm{Ba}$ \\
\hline$\left(199 / 216 \mathrm{~L} \mathrm{ha}^{-1}\right)$ & $13.8 \mathrm{Aa}$ & $4.5 \mathrm{Ba}$ \\
\hline CV\% & \multicolumn{2}{|r|}{9.43} \\
\hline \multicolumn{3}{|c|}{ Lower Third $^{3}$} \\
\hline & \multicolumn{2}{|c|}{ Application speed } \\
\hline Application Rate & $5 \mathrm{~km} \mathrm{~h}^{-1}$ & $16 \mathrm{~km} \mathrm{~h}^{-1}$ \\
\hline$\left(108 / 110 \mathrm{~L} \mathrm{ha}^{-1}\right)$ & $4.3 \mathrm{a}$ & $0.0 \mathrm{~b}$ \\
\hline$\left(199 / 216 \mathrm{~L} \mathrm{ha}^{-1}\right)$ & $2.5 \mathrm{a}$ & $1.0 \mathrm{ab}$ \\
\hline $\mathrm{CV} \%$ & \multicolumn{2}{|r|}{35.15} \\
\hline
\end{tabular}

${ }^{1}$ Means followed by the same uppercase letters in the rows and lowercase letters in the columns do not differ by Tukey test at $5 \%$ probability level. ${ }^{2} 110 \mathrm{~L} \mathrm{ha}^{-1}$ and $199 \mathrm{~L} \mathrm{ha}^{-1}$ (application at $5 \mathrm{~km} \mathrm{~h}^{-1}$ ), $108 \mathrm{~L} \mathrm{ha}^{-1}$ and $216 \mathrm{~L} \mathrm{ha}^{-}$ ${ }^{1}$ (application at $16 \mathrm{~km} \mathrm{~h}^{-1}$ ). ${ }^{3}$ Means followed by the same letter do not differ by Fisher's LSD test with Bonferroni correction.

As the leaves from the lower third of soybean plants showed less insecticide deposition, the average leaf consumption was higher when these leaves were offered, regardless of the caterpillar species (Tables 3, 4, 5 and 6).

For the leaf damage caused by Helicoverpa armigera in the leaves collected at 1 DAA (Table 3 ), there was greater leaf damage with the increase in application speed for the upper third at 3 DAI and middle and lower thirds at 7 DAI, regardless of the application rate, for the upper third at $7 \mathrm{DAI}$, at the highest rates, and for the lower third at $3 \mathrm{DAI}$, at the lowest rates. There was no difference with the reduction in application speed only for the middle third at 3 DAI, regardless of the application rate, for the upper third at 7 DAI, at the lowest rates, and for the lower third at $3 \mathrm{DAI}$, at the highest rates. In other words, of 12 comparisons, differences due to application speed were found in 8. In a comparison of the application rates, the situation is reversed, because only 4 differences were found, evidencing the influence of the reduction in the application speed on the reduction of damage.

According to Madalosso et al. (2010), chemical protection of the entire canopy, especially in the middle and lower parts, is prevented due to vegetation density. Such interruption in penetration and coverage prevents the active ingredient from performing properly, reducing its control. Studying the deposition in soybean cultivars at R1 stage, Farinha et al. (2009) found that deposits in the apical region were almost three times higher than those in the basal region, agreeing with the present study. Also, Boschini et al. (2008) showed that the spray deposits that occurred in the lower third of the soybean cultivar CD 202 were significantly lower than those obtained in the upper third, regardless of the nozzle and flow rate used. Souza (2002) points out that deposits in shorter and intermediate plants were more homogeneous. There was a reduction in the deposition per unit of leaf area with the leaf area increase and the deposits were also less uniform, evidencing that the accumulation of leaves, with overlapping, reduces the deposition per unit of leaf area.

The results of this experiment agree with those found by Forster, Zabkiewicz and Riedere (2004). Although higher application rates necessarily result in reduction in the concentration of active ingredient in the spray mixture, it promotes higher levels of leaf surface coverage by the drops, which also leads to increased absorption of this product. Coverage percentage is a variable that is related to the control efficiency of an application. Higher percentages promote an increase in control levels (AZEVEDO, 2007; FORSTER; ZABKIEWICZ; RIEDERE, 2004). Typically, larger volumes promote higher deposits under similar spray conditions (MATTHEWS, 2000). In addition, Bauer and Raetano (2004) also concluded that larger volumes promoted higher coverage by the drops sprayed on soybean plants. 
Table 3. Leaf damage (\%) caused by Helicoverpa armigera (Lepidoptera: Noctuidae) in different thirds of soybean plants with different rates and speeds of Indoxacarb application at R4 stage in offered leaf area of $19.25 \mathrm{~cm}^{2}$ for leaves collected at 1 DAA (days after application) and evaluated at 3 and 7 DAI (days after infestation). Paulínia-SP, Brazil.

\begin{tabular}{|c|c|c|c|c|}
\hline & \multicolumn{2}{|c|}{$3 \mathrm{DAI}$} & \multicolumn{2}{|c|}{$7 \mathrm{DAI}$} \\
\hline \multicolumn{5}{|c|}{ Upper Third } \\
\hline & \multicolumn{4}{|c|}{ Application Speed } \\
\hline Application Rate & $5 \mathrm{~km} \mathrm{~h}^{-1}$ & $16 \mathrm{~km} \mathrm{~h}^{-1}$ & $5 \mathrm{~km} \mathrm{~h}^{-1}$ & $16 \mathrm{~km} \mathrm{~h}^{-1}$ \\
\hline$\left(108 / 110 \mathrm{~L} \mathrm{ha}^{-1}\right)^{1}$ & $1.0 \mathrm{a}^{2}$ & $4.7 \mathrm{~b}$ & $3.3 \mathrm{a}$ & $5.0 \mathrm{a}$ \\
\hline$\left(199 / 216 \mathrm{~L} \mathrm{ha}^{-1}\right)$ & $3.7 \mathrm{~b}$ & $9.2 \mathrm{c}$ & $3.7 \mathrm{a}$ & $9.2 \mathrm{~b}$ \\
\hline \multirow[t]{3}{*}{$\mathrm{CV} \%$} & \multicolumn{2}{|c|}{26.06} & \multicolumn{2}{|c|}{35.81} \\
\hline & \multicolumn{3}{|c|}{ Middle Third } & \\
\hline & \multicolumn{4}{|c|}{ Application Speed } \\
\hline Application Rate & $5 \mathrm{~km} \mathrm{~h}^{-1}$ & $16 \mathrm{~km} \mathrm{~h}^{-1}$ & $5 \mathrm{~km} \mathrm{~h}^{-1}$ & $16 \mathrm{~km} \mathrm{~h}^{-1}$ \\
\hline$\left(108 / 110 \mathrm{~L} \mathrm{ha}^{-1}\right)$ & $7.2 \mathrm{a}$ & $9.3 \mathrm{a}$ & $9.8 \mathrm{a}$ & $32.9 \mathrm{~b}$ \\
\hline$\left(199 / 216 \mathrm{~L} \mathrm{ha}^{-1}\right)$ & $5.6 \mathrm{a}$ & $8.8 \mathrm{a}$ & $8.0 \mathrm{a}$ & $18.3 \mathrm{~b}$ \\
\hline \multirow[t]{3}{*}{$\mathrm{CV} \%$} & \multirow{2}{*}{\multicolumn{3}{|c|}{51.90}} & 29.28 \\
\hline & \multicolumn{2}{|c|}{ Lower Third } & & \\
\hline & \multicolumn{4}{|c|}{ Application Speed } \\
\hline Application Rate & $5 \mathrm{~km} \mathrm{~h}^{-1}$ & $16 \mathrm{~km} \mathrm{~h}^{-1}$ & $5 \mathrm{~km} \mathrm{~h}^{-1}$ & $16 \mathrm{~km} \mathrm{~h}^{-1}$ \\
\hline$\left(108 / 110 \mathrm{~L} \mathrm{ha}^{-1}\right)$ & $9.6 \mathrm{a}$ & $15.8 \mathrm{~b}$ & $48.8 \mathrm{a}$ & $57.1 \mathrm{bc}$ \\
\hline$\left(199 / 216 \mathrm{~L} \mathrm{ha}^{-1}\right)$ & $14.6 \mathrm{~b}$ & $25.8 \mathrm{~b}$ & $51.7 \mathrm{ab}$ & $60.0 \mathrm{c}$ \\
\hline $\mathrm{CV} \%$ & \multicolumn{2}{|c|}{39.89} & \multicolumn{2}{|c|}{46.39} \\
\hline Control & \multicolumn{2}{|c|}{27.9} & \multicolumn{2}{|c|}{60.8} \\
\hline
\end{tabular}

In regard to the damage caused by Chrysodeixis includens in the leaves collected at 1 DAA (Table 4), in the upper third there was no significant difference in damage due to the good coverage for the lowest application rate, regardless of the speeds adopted. For the rate from 199 to $216 \mathrm{~L}$ $\mathrm{ha}^{-1}$, there was greater damage at the speed of $16 \mathrm{~km}$ $\mathrm{h}^{-1}$. For the middle third at $7 \mathrm{DAI}$, there was influence of the application speed, and the lowest speed $\left(5 \mathrm{~km} \mathrm{~h}^{-1}\right)$ was more efficient in controlling the pest, regardless of the application rate. For the lower third, the amount of product that was distributed, regardless of the application technology adopted, was not enough to ensure good performance, and the results were similar to those found in the control. Thus, the trend was the same as that found in the evaluations of Helicoverpa armigera.

As reported by Waquil (2008), the fact that pests remain inside the canopy hinders their control due to the lower exposure to the insecticide during the daytime period. Campos et al. (2014) found a lower number of Spodoptera frugiperda caterpillars when the application was directed to the crop row, with no difference between the volumes applied, which were 50,100 and $150 \mathrm{~L} \mathrm{ha}^{-1}$, indicating that the use of these volumes may not interfere in the control of $S$. frugiperda. In other words, reducing the application rate became feasible when the target was reached with the technology used, in this case the application directed to the crop row. Cunha and Silva Júnior (2010), studying the volumes of 130 and 200
$\mathrm{L} \mathrm{ha}^{-1}$ to control fall armyworm caterpillars, observed that for five days after application the best volume was $200 \mathrm{~L} \mathrm{ha}^{-1}$ and the best results were obtained by flat jet nozzles.

According to Maziero (2006), raising the spray volume from 50 to $150 \mathrm{~L} \mathrm{ha}^{-1}$ promotes better control, associated with increase in droplet density, especially in the middle and lower parts of the crop. Thus, part of the mist spectrum produced with larger volumes has more penetration capacity as they have a greater amount of fine drops reaching the insects and/or pods from the middle and lower parts.

According to Boller and Raetano (2011), the immediate consequence of increasing the displacement speed is the greater relative wind between the moving boom and the air layer existing between the spray boom and the target crop, exerting a brake effect, opposing the descent speed of the drops generated in the spray. This process could favor evaporation and drift, especially of the smaller drops, making it difficult to reach the canopy.

Another factor to be taken into account is the constructive characteristics of the spray nozzles. Nozzles with air induction, for generating drops with larger size and lower percentage of small drops, can be more efficient in sprays at high speeds due to the lower impact of the contrary wind on the drops formed. In addition, the inclination of the applied jet can compensate for the effect of the wind contrary to the spraying, resulting in greater uniformity of spray distribution (AGROTOP, 2008). 
Table 4. Leaf damage (\%) caused by Chrysodeixis includens (Lepidoptera: Noctuidae) in different thirds of soybean plants with different rates and speeds of Indoxacarb application at R4 stage in offered leaf area of $19.25 \mathrm{~cm}^{2}$ for leaves collected at 1 DAA (days after application) and evaluated at 3 and 7 DAI (days after infestation). Paulínia-SP, Brazil.

\begin{tabular}{|c|c|c|c|c|}
\hline & \multicolumn{2}{|c|}{$3 \mathrm{DAI}$} & \multicolumn{2}{|c|}{$7 \mathrm{DAI}$} \\
\hline \multicolumn{5}{|c|}{ Upper Third } \\
\hline \multirow[b]{2}{*}{ Application Rate } & \multicolumn{4}{|c|}{ Application Speed } \\
\hline & $5 \mathrm{~km} \mathrm{~h}^{-1}$ & $16 \mathrm{~km} \mathrm{~h}^{-1}$ & $5 \mathrm{~km} \mathrm{~h}^{-1}$ & $16 \mathrm{~km} \mathrm{~h}^{-1}$ \\
\hline$\left(108 / 110 \mathrm{~L} \mathrm{ha}^{-1}\right)^{1}$ & $1.0 \mathrm{a}^{2}$ & $1.8 \mathrm{a}$ & $3.7 \mathrm{a}$ & $4.0 \mathrm{a}$ \\
\hline$\left(199 / 216 \mathrm{~L} \mathrm{ha}^{-1}\right)$ & $1.7 \mathrm{a}$ & $4.0 \mathrm{~b}$ & $3.9 \mathrm{a}$ & $7.1 \mathrm{~b}$ \\
\hline $\mathrm{CV} \%$ & \multicolumn{2}{|c|}{38.39} & \multicolumn{2}{|c|}{43.67} \\
\hline \multicolumn{5}{|c|}{ Middle Third } \\
\hline & \multicolumn{4}{|c|}{ Application Speed } \\
\hline Application Rate & $5 \mathrm{~km} \mathrm{~h}^{-1}$ & $16 \mathrm{~km} \mathrm{~h}^{-1}$ & $5 \mathrm{~km} \mathrm{~h}^{-1}$ & $16 \mathrm{~km} \mathrm{~h}^{-1}$ \\
\hline$\left(108 / 110 \mathrm{~L} \mathrm{ha}^{-1}\right)$ & $4.2 \mathrm{~b}$ & $2.5 \mathrm{a}$ & $4.2 \mathrm{a}$ & $10.3 \mathrm{~b}$ \\
\hline$\left(199 / 216 \mathrm{~L} \mathrm{ha}^{-1}\right)$ & $2.3 \mathrm{a}$ & $3.7 \mathrm{ab}$ & $4.7 \mathrm{a}$ & $14.2 \mathrm{c}$ \\
\hline $\mathrm{CV} \%$ & \multicolumn{2}{|c|}{46.95} & \multicolumn{2}{|c|}{27.68} \\
\hline \multicolumn{5}{|c|}{ Lower Third } \\
\hline & \multicolumn{4}{|c|}{ Application Speed } \\
\hline Application Rate & $5 \mathrm{~km} \mathrm{~h}^{-1}$ & $16 \mathrm{~km} \mathrm{~h}^{-1}$ & $5 \mathrm{~km} \mathrm{~h}^{-1}$ & $16 \mathrm{~km} \mathrm{~h}^{-1}$ \\
\hline$\left(108 / 110 \mathrm{~L} \mathrm{ha}^{-1}\right)$ & $12.9 \mathrm{a}$ & $13.3 \mathrm{a}$ & $52.9 \mathrm{a}$ & $55.0 \mathrm{a}$ \\
\hline$\left(199 / 216 \mathrm{~L} \mathrm{ha}^{-1}\right)$ & $14.6 \mathrm{a}$ & $15.7 \mathrm{a}$ & $54.6 \mathrm{a}$ & $60.0 \mathrm{a}$ \\
\hline $\mathrm{CV} \%$ & \multicolumn{2}{|c|}{49.78} & \multicolumn{2}{|c|}{51.02} \\
\hline Control & \multicolumn{2}{|c|}{17.5} & \multicolumn{2}{|c|}{61.7} \\
\hline
\end{tabular}

${ }^{1} 110 \mathrm{~L} \mathrm{ha}^{-1}$ and $199 \mathrm{~L} \mathrm{ha}^{-1}$ (application at $5 \mathrm{~km} \mathrm{~h}^{-1}$ ), $108 \mathrm{~L} \mathrm{ha}^{-1}$ and $216 \mathrm{~L} \mathrm{ha}^{-1}$ (application at $16 \mathrm{~km} \mathrm{~h}^{-1}$ ).

${ }^{2}$ Means followed by the same letter do not differ by Fisher's LSD test with Bonferroni correction.

The insecticide Indoxacarb has low residual effect due to its high photodegradation $\left(\mathrm{DT}_{50}=4.5\right.$ days at $\mathrm{pH} 5$ and $25{ }^{\circ} \mathrm{C}$ ) (EMMANOUIL et al., 2013). In addition to this characteristic, another factor to be considered in the reduction of efficacy is related to the occurrence of rainfall. The action of water can remove part of the product deposited on the leaflet, reducing its absorption and protection period (ARRUÉ et al., 2014).

To verify the influence of application technology on the residual period, that is, on the degradation of the product in the plant, leaves collected at 7 DAA were infested with caterpillars (Tables 5 and 6).

In the evaluation of damage caused by Helicoverpa armigera at 3 and 7 DAI, for the upper, middle and lower thirds, it was evident that the largest deposits of the product occurred at the lowest speeds $\left(5 \mathrm{~km} \mathrm{~h}^{-1}\right)$ and the highest rates (199 to $216 \mathrm{~L}$ $\mathrm{ha}^{-1}$ ), ensuring the best control (Table 5), especially at 3 DAI in the middle third and at 7 DAI in the lower third. In addition, for the lower third, due to the low deposition, all treatments showed a large amount of damage. Vinaykumar et al. (2013) reported efficacy of Indoxacarb in the control of $H$. armigera caterpillars in soybean crop until seven days after application.

In the evaluations of Chrysodeixis includens, the trend presented previously was not so evident (Table 6). For the middle and lower thirds, there was no difference in damage as a function of the technology adopted, with all treatments being equivalent. In the lower third, the amount of product deposited was not sufficient to ensure residual effect on these evaluations.

The control of these defoliating species is important in the vegetative and reproductive stages. In the reproductive stage, the period addressed in this study, the plant has the highest leaf area index, which makes it difficult for the products to reach the targets of the middle and lower thirds.

When the applied insecticides do not reach the middle regions, where $C$. includens caterpillars are, the direct consequence is the need for more applications (DEGRANDE; VIVIAN, 2010), although this may cause imbalance of the ecosystem. For Helicoverpa armigera, the intensity of economic damage occurs because the caterpillars feed on leaves, floral buds, pods and grains (CZEPAK et al., 2013; SPECHT et al., 2013), which highlights the importance of performing good canopy coverage throughout the cycle.

The success of chemical control in agriculture depends on effective products, adequate equipment and technologies, and favorable environmental conditions. The mixture volume to be used in a spray depends on the mode of action and formulation of the phytosanitary product, type and degree of development of the target, weather conditions at the time of application and the device used for application (GADANHA JUNIOR; ZAIDAN 2004). 
Table 5. Leaf damage (\%) caused by Helicoverpa armigera (Lepidoptera: Noctuidae) in different thirds of soybean plants with different rates and speeds of Indoxacarb application at R4 stage in offered leaf area of $19.25 \mathrm{~cm}^{2}$ for leaves collected at 7 DAA (days after application) and evaluated at 3 and 7 DAI (days after infestation). Paulínia-SP, Brazil.

\begin{tabular}{|c|c|c|c|c|}
\hline & \multicolumn{2}{|c|}{3 DAI } & \multicolumn{2}{|c|}{7 DAI } \\
\hline \multicolumn{5}{|c|}{ Upper Third } \\
\hline & \multicolumn{4}{|c|}{ Application Speed } \\
\hline Application Rate & $5 \mathrm{~km} \mathrm{~h}^{-1}$ & $16 \mathrm{~km} \mathrm{~h}^{-1}$ & $5 \mathrm{~km} \mathrm{~h}^{-1}$ & $16 \mathrm{~km} \mathrm{~h}^{-1}$ \\
\hline$\left(108 / 110 \mathrm{~L} \mathrm{ha}^{-1}\right)^{\mathrm{T}}$ & $2.3 \mathrm{a}^{2}$ & $4.6 \mathrm{~b}$ & $2.0 \mathrm{a}$ & $11.7 \mathrm{~b}$ \\
\hline$\left(199 / 216 \mathrm{~L} \mathrm{ha}^{-1}\right)$ & $1.3 \mathrm{a}$ & $6.2 \mathrm{~b}$ & $3.6 \mathrm{a}$ & $13.6 \mathrm{~b}$ \\
\hline $\mathrm{CV} \%$ & \multicolumn{2}{|c|}{45.23} & \multicolumn{2}{|c|}{40.34} \\
\hline \multicolumn{5}{|c|}{ Middle Third } \\
\hline & \multicolumn{4}{|c|}{ Application Speed } \\
\hline Application Rate & $5 \mathrm{~km} \mathrm{~h}^{-1}$ & $16 \mathrm{~km} \mathrm{~h}^{-1}$ & $5 \mathrm{~km} \mathrm{~h}^{-1}$ & $16 \mathrm{~km} \mathrm{~h}^{-1}$ \\
\hline$\left(108 / 110 \mathrm{~L} \mathrm{ha}^{-1}\right)$ & $4.2 \mathrm{ab}$ & $8.0 \mathrm{~b}$ & $4.0 \mathrm{a}$ & $22.9 \mathrm{c}$ \\
\hline$\left(199 / 216 \mathrm{~L} \mathrm{ha}^{-1}\right)$ & $3.0 \mathrm{a}$ & $5.7 \mathrm{~b}$ & $3.6 \mathrm{a}$ & $10.4 \mathrm{~b}$ \\
\hline $\mathrm{CV} \%$ & \multicolumn{2}{|c|}{45.58} & \multicolumn{2}{|c|}{23.74} \\
\hline \multicolumn{5}{|c|}{ Lower Third } \\
\hline & \multicolumn{4}{|c|}{ Application Speed } \\
\hline Application Rate & $5 \mathrm{~km} \mathrm{~h}^{-1}$ & $16 \mathrm{~km} \mathrm{~h}^{-1}$ & $5 \mathrm{~km} \mathrm{~h}^{-1}$ & $16 \mathrm{~km} \mathrm{~h}^{-1}$ \\
\hline$\left(108 / 110 \mathrm{~L} \mathrm{ha}^{-1}\right)$ & $13.8 \mathrm{a}$ & $14.6 \mathrm{a}$ & $69.2 \mathrm{~b}$ & $60.8 \mathrm{ab}$ \\
\hline$\left(199 / 216 \mathrm{~L} \mathrm{ha}^{-1}\right)$ & $19.2 \mathrm{a}$ & $17.5 \mathrm{a}$ & $57.5 \mathrm{a}$ & $66.7 \mathrm{~b}$ \\
\hline $\mathrm{CV} \%$ & \multicolumn{2}{|c|}{52.01} & \multicolumn{2}{|c|}{49.08} \\
\hline Control & \multicolumn{2}{|c|}{21.3} & \multicolumn{2}{|c|}{84.2} \\
\hline
\end{tabular}

Table 6. Leaf damage (\%) caused by Chrysodeixis includens (Lepidoptera: Noctuidae) in different thirds of soybean plants with different rates and speeds of Indoxacarb application at R4 stage in offered leaf area of $19.25 \mathrm{~cm}^{2}$ for leaves collected at 7 DAA (days after application) and evaluated at 3 and 7 DAI (days after infestation). Paulínia-SP, Brazil.

\begin{tabular}{|c|c|c|c|c|}
\hline & \multicolumn{2}{|c|}{$3 \mathrm{DAI}$} & \multicolumn{2}{|c|}{$7 \mathrm{DAI}$} \\
\hline \multicolumn{5}{|c|}{ Upper Third } \\
\hline & \multicolumn{4}{|c|}{ Application Speed } \\
\hline Application Rate & $5 \mathrm{~km} \mathrm{~h}^{-1}$ & $16 \mathrm{~km} \mathrm{~h}^{-1}$ & $5 \mathrm{~km} \mathrm{~h}^{-1}$ & $16 \mathrm{~km} \mathrm{~h}^{-1}$ \\
\hline$\left(108 / 110 \mathrm{~L} \mathrm{ha}^{-1}\right)^{1}$ & $1.7 \mathrm{a}^{2}$ & $2.3 \mathrm{ab}$ & $2.8 \mathrm{a}$ & $5.4 \mathrm{~b}$ \\
\hline$\left(199 / 216 \mathrm{~L} \mathrm{ha}^{-1}\right)$ & $2.0 \mathrm{ab}$ & $3.7 \mathrm{~b}$ & $3.2 \mathrm{a}$ & $4.8 \mathrm{ab}$ \\
\hline $\mathrm{CV} \%$ & \multicolumn{2}{|c|}{48.46} & \multicolumn{2}{|c|}{45.47} \\
\hline \multicolumn{5}{|c|}{ Middle Third } \\
\hline & \multicolumn{4}{|c|}{ Application Speed } \\
\hline Application Rate & $5 \mathrm{~km} \mathrm{~h}^{-1}$ & $16 \mathrm{~km} \mathrm{~h}^{-1}$ & $5 \mathrm{~km} \mathrm{~h}^{-1}$ & $16 \mathrm{~km} \mathrm{~h}^{-1}$ \\
\hline$\left(108 / 110 \mathrm{~L} \mathrm{ha}^{-1}\right)$ & $2.5 \mathrm{a}$ & $3.4 \mathrm{a}$ & $4.8 \mathrm{a}$ & $7.3 \mathrm{a}$ \\
\hline$\left(199 / 216 \mathrm{~L} \mathrm{ha}^{-1}\right)$ & $4.8 \mathrm{a}$ & $4.5 \mathrm{a}$ & $6.5 \mathrm{a}$ & $6.7 \mathrm{a}$ \\
\hline $\mathrm{CV} \%$ & \multicolumn{2}{|c|}{54.60} & \multicolumn{2}{|c|}{55.48} \\
\hline \multicolumn{5}{|c|}{ Lower Third } \\
\hline & \multicolumn{4}{|c|}{ Application Speed } \\
\hline Application Rate & $5 \mathrm{~km} \mathrm{~h}^{-1}$ & $16 \mathrm{~km} \mathrm{~h}^{-1}$ & $5 \mathrm{~km} \mathrm{~h}^{-1}$ & $16 \mathrm{~km} \mathrm{~h}^{-1}$ \\
\hline$\left(108 / 110 \mathrm{~L} \mathrm{ha}^{-1}\right)$ & $13.3 \mathrm{a}$ & $18.8 \mathrm{a}$ & $60.8 \mathrm{a}$ & $63.3 \mathrm{a}$ \\
\hline$\left(199 / 216 \mathrm{~L} \mathrm{ha}^{-1}\right)$ & $21.7 \mathrm{a}$ & $19.2 \mathrm{a}$ & $54.5 \mathrm{a}$ & $64.2 \mathrm{a}$ \\
\hline $\mathrm{CV} \%$ & \multicolumn{2}{|c|}{49.97} & \multicolumn{2}{|c|}{53.52} \\
\hline Control & \multicolumn{2}{|c|}{20.4} & \multicolumn{2}{|c|}{73.3} \\
\hline
\end{tabular}

\section{CONCLUSION}

For the conditions used in the present experiment, the increase in application rates from $108-110$ to $199-216 \mathrm{~L} \mathrm{ha}^{-1}$ did not result in significant coverage increments in the evaluated thirds. In regard to the application speed, the reduction from $16 \mathrm{~km} \mathrm{~h}^{-1}$ to $5 \mathrm{~km} \mathrm{~h}^{-1}$ promoted a significant increase in coverage for the upper and middle thirds, regardless of the application rate adopted. For efficacy parameters, the highest leaf coverage by the insecticide Indoxacarb (15\% EC) 
$\left(\right.$ Avatar $\left.^{\circledR}\right)$, observed in the upper third of the canopy, resulted in lower leaf damage, regardless of the application technology adopted. For the middle and lower thirds, the reduction in speed had more influence on the decrease in leaf damage than the increase in volume.

\section{REFERENCES}

AGROTOP. Düsen und Zubehör für den Pflanzenschutz: Produktkatalog 106. Obertraubling: Agrotop GmbH, 2008. 128 p.

ARRUÉ, A. et al. Precipitação artificial após aplicação do inseticida clorantraniliprole associado com adjuvante em plantas de soja. Ciência Rural, 12: $2118-2123,2014$

AVILA, C. J.; VIVAN, L. M.; TOMQUELSKI, G. V. Ocorrência, aspectos biológicos, danos e estratégias de manejo de Helicoverpa armigera (Hübner) (Lepidoptera: Noctuidae) nos sistemas de produção agrícolas. Dourados, MS: Embrapa Agropecuária Oeste, 2013. 12 p. (Circular Técnica, 23).

AZEVEDO, L. A. S. Fungicidas sistêmicos: teoria e prática. 1.ed. Campinas, SP: EMOPI, 2007. 283 p.

BALAN, M. G. et al. Deposição da calda pulverizada por três pontas de pulverização sob diferentes condições meteorológicas. Semina: Ciências Agrárias, 29: 293-298, 2008.

BAUER, F. C.; RAETANO, C. G. Distribuição volumétrica de calda produzida pelas pontas de pulverização XR, TP e TJ sob diferentes condições operacionais. Planta Daninha, 22: 275-284, 2004.

BOLLER, W.; RAETANO, C. G. Bicos e pontas de pulverização de energia hidráulica, regulagem e calibração de pulverizadores de barra. In: ANTUNIASSI, U. R.; BOLLER, W. (1. ed.). Tecnologia de aplicação para culturas anuais. Passo Fundo, RS: Aldeia Norte; Botucatu, SP: FEPAF, 2011. v. 1, p. 51-80.

BOSCHINI, L. et al. Avaliação da deposição da calda de pulverização em função da vazão e do tipo de bico hidráulico na cultura da soja. Acta Scientiarum Agronomy, 30: 171-175, 2008.

CAMPOS, H. B. N. et al. Localized application of insecticide combined with fertilizer on corn controls Spodoptera frugiperda (Smith) and reduces spray drift. International Journal of Agricultural Research, 9: 200-209, 2014.
CANTERI, M. G. et al. Conta-gotas: sistema para análise de eficiência de pulverização. In: CONGRESSO PAULISTA DE FITOPATOLOGIA, 27., 2001. Piracicaba, SP. Anais... Jaboticabal: Grupo Paulista de Fitopatologia, 2001, p. 136.

CONOVER, W. J. Practical Nonparametric Statistics. Third Edition, John Wiley \& Sons, New York, 1999.

CUNHA, J. P. A. R.; SILVA JUNIOR, A. D. S. Volumes de calda e pontas de pulverização no controle químico de Spodoptera frugiperda na cultura do sorgo forrageiro. Engenharia Agrícola 30: 692-699, 2010.

CZEPAK, C. et al. Primeiro registro de ocorrência de Helicoverpa armigera (Hübner) (Lepidoptera: Noctuidae) no Brasil. Pesquisa Agropecuária Tropical, 43: 110-113, 2013.

DEGRANDE, P. E; VIVIAN, L. M. Pragas da soja. 2010. Available at: <http://www.fundacaoms.org.br/ base/www/fundacaoms.org.br/media/ attachments/138/138/newarchive-138.pdf $>$. Access on: Nov. 22, 2015.

EMMANOUIL, R. et al. Determination of baseline susceptibility of European populations of Tuta absoluta (Meyrick) to indoxacarb and chlorantraniliprole using a novel dip bioassay method. Pest Management Science, 69: 217-227, 2013

EMPRESA BRASILEIRA DE PESQUISA AGROPECUÁRIA - EMBRAPA. Centro Nacional de Pesquisa de Solos. Sistema brasileiro de classificação de solos. 1. ed. Brasília, DF: Embrapa Serviço de Produção de Informação; Rio de Janeiro, RJ: Embrapa Solos, 1999. 412 p.

FARINHA, J. V. et al. Deposição da calda de pulverização em cultivares de soja no estádio R1. Ciência Rural, 39: 1738-1744, 2009.

FORSTER, W. A.; ZABKIEWICZ, J. A.; RIEDERE, M. Mechanisms of cuticular uptake of xenobiotics into living plants: 1 . Influence of xenobiotic dose on the uptake of three model compounds applied in the absence and presence of surfactants into Chenopodium album, Hedera helix and Stephanotis floribunda leaves. Pest Management Science, 60: 1105-1113, 2004.

GADANHA JUNIOR, C. D.; ZAIDAN, S. E. Avaliação dos padrões de distribuição radial de bico de pulverização de jato cônico cheio. In: SIMPÓSIO INTERNACIONAL DE TECNOLOGIA DE APLICAÇÃO DE AGROTÓXICOS, 3., 2004, Botucatu. Anais... Botucatu: FEPAF, 2004. 267 p. 
HALLEY, S. S. et al. Fungicide deposition measurement by spray volume, drop size and sprayer system in cereal grains. Applied Engineering in Agriculture, 24: 15-21, 2008.

MADALOSSO, M. G. et al. Cultivares, espaçamento entrelinhas e programas de aplicação de fungicidas no controle de Phakopsora pachyrhizi Sidow em soja. Ciência Rural, 10: 2256- 2261, 2010.

MATTHEWS, G. A. Pesticide application methods. London: Blackwell, 2000. 448 p.

MAZIERO, H. Estudo de tecnologia de aplicação e inseticida para o controle de percevejos fitófagos na cultura da soja. 2006. 34f. Dissertação (Mestrado em Agronomia: Área de Concentração em Produção Vegetal) - Universidade Estadual de Santa Maria, Santa Maria, 2006.

REIS, E. F. Dependência espacial da deposição de calda promovida por uma aplicação aérea na cultura da soja. Revista Caatinga, 25: 79-85, 2012.

ROMÁN, R. A. A. et al. Cobertura da cultura da soja pela calda fungicida em função de pontas de pulverização e volumes de aplicação. Scientia Agraria, 10: 223-232, 2009.

SOUZA, R. T. Efeito de eletrização de gotas sobre a variabilidade dos depósitos de pulverização e eficácia do glyphosate no controle de plantas daninhas da cultura da soja. 2002. vi, $69 \mathrm{f}$. Tese (Doutorado em Agronomia: Área de Concentração em Agricultura) - Faculdade de Ciências Agronômicas, Universidade Estadual Paulista, Botucatu, 2002.

SPECHT, A. et al. Identificação morfológica e molecular de Helicoverpa armigera (Lepidoptera: Noctuidae) e ampliação de seu registro de ocorrência no Brasil. Pesquisa Agropecuária Brasileira, 48: 689-692, 2013.

VINAYKUMAR, M. M. et al. Management of Spodoptera litura (Fabr.) and Helicoverpa armigera (Mats.) in soybean with newer insecticides. International Journal of Green and Herbal Chemistry, 2: 665-674, 2013.

WAQUIL, J. M. Cultivo do sorgo. Embrapa Milho e Sorgo. Sistemas de Produção, Versão Eletrônica - $4^{\mathrm{a}}$ edição, Setembro, 2008. Disponível em: <https:// www.alice.cnptia.embrapa.br/bitstream/ doc/491922/4/pragas.pdf $>$. Acesso em: 27 out. 2015.

WEBER, N. C. et al. Deposição de calda ao longo do dossel na cultura da soja utilizando pulverizador equipado com controlador de fluxo, Revista Engenharia na Agricultura, 25: 459-468, 2017. 